https://helda.helsinki.fi

\title{
Locking in Constitutionality Control in Finland
}

\section{Husa, Jaakko}

2020-06

Husa , J 2020 , ' Locking in Constitutionality Control in Finland ', European Constitutional Law Review , vol. 16 , no. 2 , pp. 249-274 . https://doi.org/10.1017/S1574019620000139

http://hdl.handle.net/10138/321462

https://doi.org/10.1017/S1574019620000139

cc_by_nc_nd

acceptedVersion

Downloaded from Helda, University of Helsinki institutional repository.

This is an electronic reprint of the original article.

This reprint may differ from the original in pagination and typographic detail.

Please cite the original version. 


\title{
Locking in Constitutionality Control in Finland
}

\author{
Jaakko Husa ${ }^{*}$
}

\begin{abstract}
Monitoring the constitutionality of laws in Finland - Political control rather than judicial control - Understanding why requires a study of historical layers - Evidence that at several historical points certain elemental choices were locked in - Resulting difficulties in later abolishing or changing patterns - Interactive relationship between the political and the legal Finland's constitutional past still circumscribes the role of the judiciary in constitutionality control
\end{abstract}

\section{$<\mathrm{H} 1>$ Introduction}

Today, constitutional review by courts lies at the heart of liberal constitutional systems. This state of affairs reflects the rise of legal constitutionalism over political constitutionalism, and the judicialisation of politics. ${ }^{1}$ In many countries, courts play a significant role in gatekeeping the constitutionality of laws, thus upholding the hierarchy of norms. Some countries maintain separate constitutional courts whereas others rely on supreme courts or operate a decentralised form of review. ${ }^{2}$ In any case, monitoring (controlling) the constitutionality of laws seems to be mostly a task for judicial organs. Even such a system as that in the United Kingdom, with its uncodified constitution lacking a clear hierarchy of norms, now has a superior court that performs de facto judicial review. ${ }^{3}$

Against the backdrop of liberal constitutionalism, the Nordic countries seem to stand out because the courts there play but a modest role in ensuring the constitutionality of laws, except in Norway where judicial review is rooted in the system. ${ }^{4}$ Of the Nordic systems, Finland stands out because of its deeply embedded system of a parliament-focused preventive model of constitutionality control that keeps the courts in a minor role even though the constitution allows judicial review. ${ }^{5}$

\footnotetext{
${ }^{*}$ Professor in Law and Globalisation at the Faculty of Law, University of Helsinki, Finland; email jaakko.husa@helsinki.fi. I am thankful for the formative criticism of the editors and anonymous peer reviewers. The usual disclaimers apply.

${ }^{1}$ R. Hirschl, 'The New Constitution and the Judicialization of Pure Politics Worldwide', 75 Fordham Law Review (2006) p. 721.

${ }^{2}$ See, e.g., M. de Visser, Constitutional Review in Europe (Hart Publishing 2014).

${ }^{3}$ See, e.g., E. Delaney, 'Judiciary rising: Constitutional change in the United Kingdom', 108 Northwestern University Law Review (2014) p. 543. See also A. Kavanagh, 'Constitutional Review, the Courts, and Democratic Scepticism', 62 Current Legal Problems (2009) p. 102.

${ }^{4}$ A. Kierulf, Judicial Review in Norway: A Bicentennial Debate (Cambridge University Press 2018).

${ }^{5}$ J. Husa, 'Constitutional Mentality', in P. Letto-Vanamo et al. (eds.), Nordic Law in European Context (Springer 2019) p. 41-60.
} 
Parliament's important role in constitutionality control is not unheard of because lack of constitutional judicial review is typical of the British-Scandinavian family of constitutional traditions. ${ }^{6}$ However, even in this family the Finnish model stands out because of the institutional manner in which it organises constitutionality control of parliamentary laws. In a comparative view, the Finnish system looks peculiar, which may give rise to misunderstandings as to how Finnish constitutionalism works. From a reading of the text of the Constitution Act (2000), it is impossible to grasp how central a constitutional role the Constitutional Law Committee plays based on customary constitutional law. ${ }^{7}$ Constitutional customs remain opaque to the outside observer and behind a language barrier in that not all official texts are translated into English or indeed any other major language. ${ }^{8}$

In a comparative context, the Finnish system is interesting because it seemingly places parliamentarians, as committee members, in such a special place while constraining courts in a minor role. This goes against the worldwide current of legal constitutionalism and the growing power of judicial organs. ${ }^{9}$ Among European countries Finland is, however, not completely alone in choosing this way as the Netherlands example shows, although Finland has no formal ban on constitutional judicial review which is the case in Netherlands. ${ }^{10}$ Because Finland is a member of the European Union (since 1995) and has ratified the European Convention on Human Rights (1990), it may be instinctive to expect stronger judicial review - and the reverse for politicians playing such an apparently significant role in terms of ensuring the constitutionality of laws. ${ }^{11} \mathrm{~A}$ general trend for decades has been the spread of judicial review-centred legal constitutionalism

\footnotetext{
${ }^{6}$ L. Besselink, 'Constitutional adjudication in the era of globalization: The Netherlands in comparative perspective', 18 European Public Law (2012) p. 231 at p. 233.

${ }^{7}$ The Constitution of Finland (731/1999, amendments up to 817/2018 included), translation from Finnish. Legally binding only in Finnish and Swedish. In Finnish and Swedish, however, this Act is titled perustuslaki/grundlag, i.e. 'basic Law', not valtiosääntö (constitution).

${ }^{8}$ The Finnish language sets an obstacle to researchers unable to read it. Even though the country is officially bilingual (Finnish and Swedish), full access to all sources requires skills in Finnish. P. Talroth, 'Multilingualism in Finland: A Legal Perspective', 1 International Journal of Language \& Law (2012) p. 33. ${ }^{9}$ T. Ginsburg, 'The Global Spread of Constitutional Review', in K. Whittington and D. Keleman (eds.), The Oxford Handbook of Law and Politics (Oxford University Press 2008) p. 81.

${ }^{10}$ See, e.g., J. de Poorter, 'Constitutional Review in the Netherlands: A Joint Responsibility', 9 Utrecht Law Review (2013) p. 89 and de Visser, supra n. 2, p. 11 ff. Art. 120 of the Constitution of the Kingdom of the Netherlands provides that 'The constitutionality of Acts of Parliament and treaties shall not be reviewed by the courts' (De rechter treedt niet in de beoordeling van de grondwettigheid van wetten en verdragen).

${ }^{11}$ Combining rights-oriented legal constitutionalism and legislature-oriented political constitutionalism has proved to be an arduous task in the Nordic systems: J. Husa, 'Nordic Constitutionalism and European Human Rights: Mixing Oil and Water?', 55 Scandinavian Studies in Law (2010) p. 102.
} 
across the globe so that today it is regarded as a part of democracy itself. ${ }^{12}$ Notwithstanding, Finland does well in the international democracy rankings and its judicial institutions are independent from the executive. ${ }^{13}$ Hence, a paradox is present: a democratic liberal system of government that still relies on political constitutionalism and shies away from constitutional judicial review. ${ }^{14}$

This article argues that an understanding of the Finnish system of monitoring constitutionality requires an examination of the historical layers of Finland's constitutional system. ${ }^{15}$ In general, the idea is simply that past events influence future events. ${ }^{16}$ The thrust of this article is that we can distinguish historical events that are locked in, amounting to a non-judicial form of constitutionality control. Even though this point is made on the basis of the Finnish case, it may possess a validity that is more general. It will be shown that certain constitutional choices were locked in at certain historical points so that they had significant implications in terms of how the system came to be as it is today. The article explains how political and legal constitutionalism can develop together in an interactive relationship in which the political and the legal are intertwined. With that in mind, the article not only explores the Finnish system but also highlights the relationship between the political and the legal, and how basic choices become locked in so that institutional arrangements change less than might be expected even when statutory law changes.

Further, the article argues that path dependence is a phenomenon that shows how past events matter, so that an individual system of governance acquires the tenacity to go against global trends

\footnotetext{
${ }^{12}$ D. Lustig and J.H.H. Weiler, 'Judicial review in the contemporary world - retrospective and prospective', 16 International Journal of Constitutional Law (2018) p. 315.

${ }^{13}$ E.g. in the 2018 World Economic Forum global judicial independence ranking, Finland ranks in first place. Norway is in third place, Denmark is $12^{\text {th }}$, and Sweden 13th: /https://reports.weforum.org/pdf/gci-2017-2018scorecard/WEF_GCI_2017_2018_Scorecard_EOSQ144.pdf), visited 9 July 2020.

${ }^{14}$ As Hirschl puts it: 'even a cursory look at relevant data suggests that the supposed correlation between courts and judicial review as independent variables and democracy as a dependent one may not be nearly as organic and natural as it has been portrayed by proponents of the canonical view. Sweden, Finland, Norway, and Denmark - four of the most developed and prosperous nations on Earth - have long adhered to social democracy while being less than enthusiastic (to put it mildly) about the American notion of rights and judicial review': R. Hirschl, Comparative Matters: The Renaissance of Comparative Constitutional Law (Oxford University Press 2014) p. 180.

${ }^{15}$ For a concise historical view, see P. Kastari, 'The Historical Background of Finnish Constitutional Ideas', 7 Scandinavian Studies in Law (1963) p. 61.

${ }^{16}$ J. Mahoney, 'Path Dependence in Historical Sociology', 29 Theory and Society (2000) p. 507 at p. 508 510.
} 
to remain at least partially idiosyncratic. ${ }^{17}$ Nevertheless, it is important to go beyond the simple notion that 'history matters'. The role of constitutional history, that is, the historical path of a constitution as a broader body of constitutional rules, is essential because it demonstrates how institutional patterns can become locked in, hence making it very difficult to abolish or change these patterns later. ${ }^{18}$ This, in turn, demonstrates the strength of both legal and political culture for a system that evolves gradually without drastic internal changes.

The article is structured under five headings. The first concerns the revolution of 1772 and how it locked in certain institutional patterns, which became important in the 1800s. The second section explains the institutional set-up for Finnish constitutionality control, at the same time providing the backbone for the historical analysis that follows, bringing to light the parallels between past and present. Thereafter, Finland's annexation by Russia is addressed, together with how the Swedish constitutional tradition was preserved so that the focus is on the layered continuity of a core constitutional modus operandi. This leads to the birth of constitutionality control as a part of Finland's autonomy-defending politics of the late 1800s. This section also addresses constitutional reforms in the early 1900s. Last in the spotlight is how parliamentary-focused constitutionality control took root in an independent Finland from 1917 onwards. The concluding discussion restates the main argument and addresses the significance of path dependence for the future of the Finnish system of constitutionality control.

$<\mathrm{H} 1>$ Institutional set-up for constitutionality control

Finland's constitutional culture is close to the other Nordic systems, all of which employ mechanisms for reviewing the constitutionality of legislation. ${ }^{19}$ Accordingly, these systems presuppose some form of separation of powers, distinguishing especially between the legislature and the judiciary, and formal hierarchy of norms. Nevertheless, different constitutional arrangements determine how judicial review of legislation is organised. ${ }^{20}$ Denmark does not have an explicit constitutional provision covering judicial review. However, it hesitantly recognises judicial review as a part of its system. Finland and Sweden have explicit written constitutional provisions concerning judicial review, although in practice judicial review is resorted to cautiously.

\footnotetext{
${ }^{17}$ This claim is not, as such, an original one, as constitutional history is constantly referred to in legal scholarship. For a concise discussion, see M. Les Benedict, 'Constitutional History and Constitutional Theory', 108 Yale Law Journal (1999) p. 2011 (discussing Ackerman's theory).

${ }^{18}$ T. Boas, 'Conceptualizing Continuity and Change: The Composite-Standard Model of Path Dependence', 19 Journal of Theoretical Politics (2007) p. 33.

${ }^{19}$ J. Husa, 'Guarding the Constitutionality of Laws in the Nordic Countries', 48 American Journal of Comparative Law (2000) p. 345.

${ }^{20}$ Husa, supra n. 5.
} 
Norway formally added judicial review by an amendment to its Constitution Act in 2014, although judicial review has long been a part of the Norwegian system. Iceland also allows judicial review, which it regards as a non-problematic element of the constitutional system. ${ }^{21}$ In a comparative Nordic view, the most distinctive feature of the Finnish system is the modus operandi in which it monitors the constitutionality of statutory laws enacted by the parliament.

Finland, like other Nordic systems, maintains no constitutional court but all courts are allowed to perform judicial review of legislation to a certain limited extent. After the total reform of the Constitution Act in 2000, it became possible for courts to perform judicial review of legislation. ${ }^{22}$ The notion of monitoring constitutionality, however, is not limited to judicial review because, in addition to the courts, other public authorities are also obliged to interpret legislation in adherence to the Constitution and to respect constitutional and human rights. ${ }^{23}$ According to the Constitution Act (Article 106), the courts, when deciding a case, must give preference to the Constitution if applying a parliamentary Act would manifestly conflict (ilmeinen ristiriita) with the Constitution Act. In a handful of cases, starting from 2004, the courts have applied Article 106. However, in the overall picture judicial review by the courts plays a minor role in terms of safeguarding the constitutionality of parliamentary Acts. ${ }^{24}$

In practice, the constitutionality of laws is examined in advance, that is, even before an act enters into force. Review mainly takes place in the parliament's influential Constitutional Law Committee (perustuslakivaliokunta). The key function of this parliamentary-bound control is advance prevention of laws that conflict with the Constitution being enacted in the ordinary legislative procedure. From the constitutional point of view, the Committee's key function is to issue statements on Bills sent to it for consideration (not all Bills undergo Committee review) and on the constitutionality of other legislative matters and their bearing on international human rights. ${ }^{25}$ While the Committee members are ordinary members of the parliament, the Committee calls experts (based on constitutional convention, explained further below) to give evidence, and the Committee itself operates in a non-party-political manner in reporting to the parliament. These experts are

\footnotetext{
${ }^{21}$ E. Helgadóttir, 'Nonproblematic Judicial Review: A Case Study', 9 International Journal of Constitutional Law (2011) p. 532.

${ }^{22}$ See V-P. Hautamäki, 'Novel Rules in the Finnish Constitution - The Question of Applicability', 52 Scandinavian Studies in Law (2007) p. 133.

${ }^{23}$ Article 22 of the Constitutional Act provides that all 'public authorities shall guarantee the observance of basic rights and liberties and human rights'.

${ }^{24}$ See J. Husa, The Constitution of Finland - A Contextual Analysis (Hart Publishing 2011) p. 186-187.

${ }^{25}$ The yearly number of statements is somewhere between 60 and 80 .
} 
external and, in practice, they are mostly law professors specialising in constitutional law or more generally in public law. ${ }^{26}$ The Committee's reports are legally grounded written formal statements and are respected by the government, which must seek to amend the provisions of a Bill that the Committee has found to be unconstitutional before the Bill can be passed. If the unconstitutionality is significant it means, in practice, that the Bill is withdrawn and the government has to think of another way to proceed because in the Finnish multiparty system governments do not have the required qualified majority to change the Constitution Act. ${ }^{27}$

From a comparative point of view the fact that the Constitutional Committee functions in a nonpolitical quasi-judicial manner (statements are based on the evidence given by external constitutional experts; the Committee follows its own 'precedents'; there is no party-political discipline) is significant. All this results in a system of controlling the constitutionality of legislation, a system which combines an abstract ex ante and concrete case-bound review mechanism. Importantly, the significance of the perustuslakivaliokunta is reflected in the whole legal system and its statements hold a special status as a source of law as de facto precedents. ${ }^{28}$ Only with slight exaggeration, one may characterise the weight of these statements as de facto 'constitutional precedents'. Importantly, the Committee does not say anything about the actual content of a Bill because its only concerns are constitutionality issues. In this respect, the Committee is different from all the other parliamentary committees that concentrate on the substantive issues of Bills and where members follow party discipline.

Overall, the constitutionality control system may be described as an institutional arrangement that combines a constitutional tradition of legislative supremacy and the notion of democracy as majority rule with a more recent tendency to practise rights-based judicial review of parliamentary legislation that arises from the national constitution and European commitments. ${ }^{29}$

\footnotetext{
${ }^{26}$ See I. Koivisto, 'Experts and Constitutionality Control in Finland: a Crisis of Cognitive Authority?', 40 Retfaerd (2017) p. 22.

${ }^{27}$ Legislative matters are constitutionally so-called ordinary matters; s. 41 of the Constitution Act provides that 'Decisions in plenary session are made by a simple majority of the votes cast, unless specifically otherwise provided in this Constitution'. In the case of enacting, amending or repealing the Constitution Act the procedure consists of two parts: first, a majority of the votes cast leaves the proposal in abeyance; second, after the following parliamentary elections the proposal can be passed (without material alterations) by a decision supported by at least two-thirds of the votes cast (s. 73(1)).

${ }^{28}$ See Husa, supra n. 24, p. 78-88.

${ }^{29}$ See J. Lavapuro et al., 'Rights-Based Constitutionalism in Finland and the Development of Pluralist Constitutional Review', 9 International Journal of Constitutional Law (2011) p. 505.
} 
$<\mathrm{H} 1>$ Locking in autocracy

In order to understand how the current constitutionality control of laws came to be, we must look back at those pivotal moments when essential institutional factors were born and key occurrences took place. In this case, the first lock-in moment took place in the late eighteenth century, when absolute monarchy was established by Gustav III (who ruled 1771-1792), diminishing the power of the Diet of the Estates and resulting in the end of the Age of Liberty with the introduction of the Swedish Constitution of 1772.

Swedish and Finnish history are necessarily intertwined because Finland formed the eastern part of Sweden from about 1200 to 1809 . Sweden itself became a state during the rule of Gustav Vasa (1523-1560), who organised the state in the form of a hereditary monarchy. ${ }^{30}$ Later, in the seventeenth century, the Estates were able to compel the King to recognise the competency of the Diet of the Estates (Svea rikes ständer) to take part in legislating by convening from time to time. The first genuinely constitutional document came about in 1634 when the Form of Government (1634 års regeringsform) was adopted. ${ }^{31}$ This constitution limited the powers of the monarch for the following decades. ${ }^{32}$ In essence, the monarch could not rule alone as an absolute monarch, but had to act together with his council (med råds råde, meaning 'with the council's advice'), and also had to take advice from the Estates in matters concerning taxation. ${ }^{33}$

The turn of events in the early eighteenth century did not mean a radical change, in that constitutional continuity from the previous century was surprisingly unbroken. Importantly, the 1723 Form of Government (1723 års regeringsform) once again limited the powers of the monarch

\footnotetext{
${ }^{30}$ Vasa's constitutional heritage is still debated and it is not quite clear what his role was. Hence, one can ask whether he was the Father of the Nation or a tyrant: L.-O. Larsson, Gustav Vasa - Landsfader eller tyrann? (Prisma 2002).

${ }^{31}$ Although it is not quite clear what the practical significance of this constitutional document was, nevertheless it introduced a principle according to which decision-making by the monarch was bound by the law, i.e. it required the compliance of the Estates (s. 4. 'Konungen äger styra och råda borgom och landom och allom sin och cronone rätt, som lag säger'). In any case, the 1634 Act may be regarded as the starting point for a system that can be described as a constitutional system and this Act can be regarded as a de jure constitution: N. Stjernquist, Land skall med lag byggas. Sveriges statförfattningshistoria [The Land will be Built by Laws: Swedish Constitutional History] (SNS Författingsprojekt 1999) p. 14.

${ }^{32}$ The term 'constitution' is used here in a broad sense. It would be possible to use the technically more correct term 'fundamental law' (lex fundamentalis): A. Jyränki, Lakien laki [Law of the Laws] (Lakimiesliiton kustannus 1989) p. 60-61.

${ }^{33}$ P. Karonen, Pohjoinen Suurvalta: Ruotsi ja Suomi 1521-1809 [The Great Northern Power: Sweden and Finland 1521-1809] (WSOY 1999) p. 196-197.
} 
and required the monarch to comply with common decisions of the Diet of the Estates. ${ }^{34}$ In other words, power shifted further from the King to the Estates. The period from 1719 to 1772 has been called the Age of Liberty (frihetstiden). ${ }^{35}$ However, this early form of constitutional monarchy did not root deeply because of what happened in 1772, the year when the path-dependent relevant lockin took place. At first, though, the powers of the monarch were not reinstated during the years 17191723 when a new constitutional document was adopted. ${ }^{36}$ Later, this state of affairs was to change drastically.

The harsh winds of constitutional backsliding blew strongly in the last decades of the eighteenth century. The Age of Liberty ended suddenly in 1772 when Gustav III turned back the constitutional clock by reasserting royal power over the Diet. His coup, although containing a military threat, was bloodless but at the same time meant a significant shift in the power structure of governance. Even though the Constitution of 1772 was, in part, also inspired by the Enlightenment and the ideas of Montesquieu, in practice it meant a strong monarchy and a weak Riksdag. ${ }^{37}$ Essentially, the King governed the state machinery and the Riksdag was assembled only at the monarch's will in cases when taxes were to be raised or new legislation was to be passed. During the Age of Liberty, the King could be described as relatively powerless because the Estates were clearly more powerful than the monarch. This all changed with the coup by Gustav III. ${ }^{38}$ In short, the Age of Liberty of the Estates was over.

Both the King and the Estates swore that the country would go back to autocracy, which the 1772 Form of Government in fact reinstated. ${ }^{39}$ In a nutshell: the Estates more or less voluntarily accepted the new Form of Government without changes. ${ }^{40}$ The new constitutional document stipulated that the King was unable to make new laws or repeal old ones without the consent of the Diet, and that

\footnotetext{
${ }^{34}$ In international literature, regeringsform is normally translated as the Instrument of Government; however, literally it means 'form of government'. Besides, the Instrument of Government refers to the constitutional document of 1653, which was a written constitution of England, Scotland, and Ireland.

${ }^{35}$ M. Roberts, The Age of Liberty: Sweden 1719-1772 (Cambridge University Press 2003).

${ }^{36} \mathrm{~J}$. Scherp, De ofrälse och makten. En institutionell studie av riksdagen och de ofrälse ståndens politik $i$ maktdelningsfrågor 1660-1682 (Stockholm University 2003).

${ }^{37}$ Karonen, supra n. 33, p. 408. The term 'Riksdag' comes from two Swedish words: 'rike' meaning the Realm and 'dag' meaning day. Together these make 'day of the Realm' i.e. the gathering day of the legislative assembly.

${ }^{38}$ C. Wolff, Noble Conceptions of Politics in Eighteenth-century Sweden (circa 1740-1790) (Studia Fennica Historica 2016) p. 29.

${ }^{39}$ Kongl. Maj:ts Nådige Försäkran Gifwen Thess trogne undersåtare Samtelige Riksens Ständer på RiksSalen Then 21 augusti 1772, Stockholm, 1772 [Kongl. Maj:ts refers to the 'Royal Majesty' i.e. Gustav III].

${ }^{40}$ Karonen, supra n. 33, p. 403.
} 
the Diet was unable to do the same without the King's consent. ${ }^{41}$ However, because the Riksdag would convene only on the King's call, in reality this meant that the monarch could rule with lowerranking decrees and by simply using political influence based on the monarch's ruling position. Later, the Deed of Association and Security (Förenings- och säkerhetsakten 1789) further strengthened the autocratic features of the system of government. The normative baseline of the Deed was clear: the King 'possesses full power to govern' and matters having to do with ruling are to be taken care of 'in the manner the King sees useful'. ${ }^{42}$ This constitutional document added new provisions to the 1772 Form of Government, thus creating a system of two constitutional documents. In practice, the Deed further strengthened the King's constitutional centrality while simultaneously seeking to further decrease the power of the aristocracy. This constitutionalised autocracy was literally 'the rule of one' (envälde) and was directly opposed to the idea of 'the rule of many' (pluralitetsvälde). ${ }^{43}$ Significantly, the Estates other than the nobility did not oppose the King's constitutional reform because it was beneficial for them, leaving the nobility dissatisfied with the monarch - and behind his later assassination. ${ }^{44}$

For Finland, the lock-in of the Swedish system of autocratic governance is evident in the fact that both constitutional documents of this period - the 1772 Form of Government and the 1789 Deed of Association and Security - remained formally in force in Finland until 1919. Every previous embryonic Finnish plan to pass a new Form of Government before 1919 was blocked because of reluctance on the part of Russia, of whose empire Finland formed part from $1809 .{ }^{45}$ In other words, these new documents formed the constitutional foundation of the Grand Duchy when Finland was part of the Russian Empire. The fact that Finland was made a constitutional autocracy in 1772 turned out to be decisive, in the sense of path dependence, for what was to follow.

\section{$<\mathrm{H} 1>$ Grand Duchy of Finland}

Due to Gustav III's coup, Finland's constitutional system, comparatively speaking, lagged behind developments elsewhere in Western Europe. With revolutionary ideas neither current nor relevant, the result was that revolutionary constitutionalism was absent. After the Finnish war (1808-1809)

\footnotetext{
${ }^{41}$ In Swedish: § 40 'Ej må Konunger någon ny Lag utan Ständernes vetskap och samtycke göra, eller någon gammal afskaffa'. § 41 'Ej måge Riksens Ständer någon gammal Lag afskaffa eller ny Lag göra, utan Konungens Ja och samtycke'.

${ }^{42}$ In Swedish (§ 1): 'äger full magt att styra' and 'på sätt konungen nyttigast synes'.

${ }^{43}$ Wolff, supra n. 38, p. 34.

${ }^{44}$ Karonen, supra n. 33, p. 416-417.

${ }^{45}$ E. Hakkila, Suomen tasavallan perustuslait [Constitutional Laws of the Republic of Finland] (WSOY 1939) p. 13-14.
} 
between Sweden and Russia, the eastern part of the realm was established as the new autonomous Grand Duchy of Finland within the Russian Empire. In hindsight, it is surprising how little actually changed even though the Russian governance model clearly differed from the Swedish one. ${ }^{46}$

After the war, the new situation required constitutional re-organisation due to the fact that 600 years with Sweden was over. The Russian Tsar Alexander I (who ruled 1801-1825) called the representatives of the Estates to convene in the town of Porvoo. At the Diet of Porvoo - actually called the Landtag, i.e. not the Riksdag - the Estates acknowledged the change in governmental power and took an oath of allegiance. ${ }^{47}$ The Estates promised loyalty to their new monarch who, in turn, declared that he would leave inherited Swedish rules in force. This was a kind of backward medieval-style occurrence, in which the Estates made a dominion pact with the sovereign ruler. In the Act of Porvoo, the former eastern part of the Swedish realm became transformed into the Grand Duchy of Finland and Alexander I became the Grand Duke of Finland. ${ }^{48}$ In effect, Finland became an autonomous part of Imperial Russia. Importantly, Finns came to regard the Act of Porvoo as a pledge according to which Finland would be governed according to its existing laws. ${ }^{49}$ This interpretation was somewhat legalistic and fitted well with Finnish views, although it is not really clear what the Tsar actually meant when he promised to uphold the privileges of the Estates and existing fundamental laws. ${ }^{50}$

\footnotetext{
${ }^{46}$ J. Kekkonen, 'The Main Trends in Finnish Legal History during the Period of Autonomy', in M. Branch et al. (eds.), Finland and Poland in the Russian Empire. A Comparative Study (School of Slavonic and East European Studies 1995) p. 105.

${ }^{47}$ Landtag refers to land, i.e. an area rather than the whole country. In other words, it is a lesser form of gathering than the Riksdag, which involves the whole country. The distinction between these two follows the German Landtag - Reichstag separation.

${ }^{48}$ The Russian approach can be regarded as a policy of pacification in Finland 1808-1809. This is described by P. Karonen, who also describes how the oath of allegiance actually took place and how it was repeated throughout Finland, in 'Introduction: Sweden, Russia and Finland 1808-1809', in C. von Heijne and T. Talvio (eds.), Monetary Boundaries in Transition. A North European Economic History and the Finnish War 1808-1809 (Museum of National Antiquities Stockholm 2010) p. 9.

${ }^{49}$ The whole pledge was actually broader and covered more than fundamental laws, i.e. the Lutheran religion, Swedish laws and legal system: Finnish translation (from Russian) in K. Grotenfelt (ed.), Suomenkielisiä historiallisia asiakirjoja Ruotsin vallan ajalta [Finnish Historical Documents from the Swedish Period] (Acta Historica Fennica 1912) p. 344-445. Of course it was not only constitutional laws but also other forms of Swedish laws such as the Swedish Law of the Realm of 1734 (1734 års lag). For a broader discussion on Swedish/Finnish private law, see H. Pihlajamäki, 'Why was private law not codified in Sweden and Finland?', in O. Moréteau et al. (eds.), Comparative Legal History (Edward Elgar Publishing 2019) p. 465 (where the 1734 Law is described as 'the jewel in the crown of Swedish statutory measures in the premodern era', at p. 477).

${ }^{50}$ Karonen, supra n. 33, p. 429. The text of the Act says that the Emperor promised to 'confirm and ratify' the religion and the fundamental laws as well as 'privileges and rights' (the sovereign's pledge was originally written in the language in which it was orally presented i.e. French; the quotations here are translated from the Swedish version).
} 
In any case, Finland's outdated constitutional laws from the eighteenth century played an important role in this, because the Russian Tsar 'would certainly not have tolerated more developed political self-governance' than that which Finland had at that time. ${ }^{51}$ Later, Finnish legal scholars fulfilled a key role in defending the constitutional position of Finland as a separate state-like entity, distinct from the rest of Russia - a view challenged, in turn, by Russian scholars. ${ }^{52}$ Throughout the eighteenth century, the budding culture of early Finnish constitutionalism mixed legal, political, and historical views and arguments when struggling to preserve its Swedish constitutional rules. The existence of written constitutional rules provided a source of legal arguments against attempts by the Russian authorities to interpret autonomy narrowly.

It may sound paradoxical but what the Tsar meant or did not mean is of less relevance here. The Finnish understanding of the importance of written constitutional rules, which came into being during the 1800 s, is important for path dependence because this understanding had a formative significance and because it substantiated how the Swedish constitutional heritage was (internally) understood and upheld in the Grand Duchy. Regardless of the fact that the exact constitutional significance of the pledge, as the Tsar himself understood it, was not clear in terms of this constitutional heritage, it was nevertheless important for constitutional path dependence. ${ }^{53}$ The significance of the constitutional documents of 1772 and 1789 became decisive partially because for decades the Tsar did not call the Diet to convene. Indeed, it was only in 1863 that the Diet was called to meet by Alexander II (ruled 1855-1881), then regularly from 1876, because new legislation required the approval of the Diet according to the Grand Duchy's constitutional laws. In other words, it took 54 years before the next Diet was held after Porvoo. Of course, new legislation was de facto passed during the years between 1809 and $1863 .{ }^{54}$ The fact that legislative reforms were carried out mainly by imperial decree meant that the constitutional framework remained officially unaltered. ${ }^{55}$ This meant, furthermore, that the constitutional practice of autocratic Sweden

\footnotetext{
${ }^{51}$ F. Lagerroth, Moderna författningar mot historisk bakgrund [Modern Constitutions against Historical Background] (Norstedts 1955) p. 192.

${ }^{52}$ HT Klami, The Legalists: Finnish Legal Science in the Period of Autonomy 1809-1917 (Finnish Society of Sciences and Letters 1981).

${ }^{53}$ O. Jussila, Suomen suuriruhtinaskunta [Grand Duchy of Finland] (WSOY 2004) p. 74-77.

${ }^{54}$ Jussila, supra n. 53, p. 232-254.

${ }^{55}$ In doing so, the Russian Emperor actually continued earlier Swedish practice following 1772; the Estates convened only on the call of the King, which meant that the King used de facto legislative power singlehandedly through administrative regulations that came into force without the consent of the Riksdag: Jyränki, supra n. 32, p. 76.
} 
was continued in the Grand Duchy: instead of a Swedish king, a Russian tsar was ruling by royal decree. The Gustavian period thus continued, albeit under a different monarchy and state structure.

As such, the period during which the Diet did not convene was not unconstitutional, in the sense that under the Deed of Association and Security the King was entitled to call the Riksdag to convene and, moreover, 'the Estates will not deal with any other matters than those proposed by the King, ${ }^{56}$ In 1863, when the Diet convened for the second time after 1809 because of growing legislative needs, the Tsar emphasised his intention to retain the constitutional powers that were his under Finland's existing fundamental laws. To that end, the Tsar accepted the transformation of the Diet into a regularly convening legislative body organised so that it was based on the Estates. The Grand Duchy of Finland's Diet consisted of four Estates, namely nobles, clergy, burghers, and peasants. During its active years, the Finnish Diet passed some 400 pieces of legislation. ${ }^{57}$ The long inactive period between 1809 and 1863 was termed 'state night' ${ }^{58}$ Now that it had ended, new legislative activity was needed. This meant a formative lock-in-phase for the Finnish model of constitutionality control, a phase built directly on the existing constitutional framework provided by the Swedish constitutional heritage and Finland's politically precarious position as a Grand Duchy. The Era of Liberal Reforms involved active legislating on matters that were needed to reform the economic system, such as freedom of contract and freedom of enterprise, which had not been neecessary under the previous mercantilism. ${ }^{59}$

A key factor behind the next step in the path was the fact that the Finns were keen to keep their constitutional laws. In practice, the majority of Finns vigorously opposed all Russian efforts to bring Finland more tightly into Russia's grip. Moreover, the idea of 'Finland' grew stronger, and there was a will to reform Finnish society according to Western European models, animated by the budding idea that Finland formed a separate nation within the Russian Empire. Finland had its own culture and language, clearly different from those of other places in the Empire. This had an effect on how the legacy of 1809 was conceived as the foundational act of a Finnish autonomous (de

\footnotetext{
${ }^{56} \S 6$ : '... Riksdag inga andra ämnen än dem konungen proponerar'. This section, then, directly refers to the constitutional law existing before the Age of Liberty by continuing that 'as was usually the case before 1680' ('på sätt som före 1860 var vanligt').

57 J. Kekkonen, “'Golden Age of Legislation” in Finland 1863-79', 2 Russian Law Journal (2014) p. 63.

${ }^{58}$ Y. Koskinen, a prominent Finnish nationalist leader of late nineteenth-century Finland, famously coined the long inactive period as 'state night' (valtioyö) or 'stateless night' by writing that '[our] state night, over a half-century long, had come to its end', Suometar 17 August 1864 (Suometar was a newspaper published from 1847 to 1866 ).

${ }^{59}$ J. Kekkonen, 'The Finnish Path to a State Based on the Rule of Law: from 1850 to the Present', in K. Nuotio et al. (eds.), Introduction to Finnish Law and Legal Culture (Forum Iuris 2012) p. 75 at p. 76-78.
} 
facto) state with its own constitutional laws. ${ }^{60}$ The existence of Swedish constitutional documents was an important part of the equation, though not the only one, in which the Swedish heritage had a constructive capacity as a legal basis on which to build without direct Russian interference.

The start of the active period of the Diet was not problem-free. Members of the Diet quickly noted that Swedish-period procedures included rules that were inadequate, contradictory, or even impossible to implement. ${ }^{61}$ The new Diet Act, accepted in 1869, was applied by the Diet until 1906. Because the Act was conceived merely as a technical reform of the earlier 1617 Order, it was not regarded as an important constitutional document. ${ }^{62}$ However, because the Diet started to convene from 1863 onwards, a more up-to-date collection of procedural rules for the Diet was required in practice. $^{63}$

\section{$<\mathrm{H} 1>$ Constitutionality control devised}

The underlying constitutional dilemma in the nineteenth century, from 1863 onwards, was how to ensure the constitutionality of new laws so that the constitutional heritage of 1772 and 1789 would stay intact in order to protect autonomy. It is important to clarify the distinction between Finnish and Russian doctrine because, as time passed, the further away from each other their constitutional views grew. ${ }^{64}$ Gradually, Finns started to think that some of the constitutional practices that were based on the earlier constitutional documents had gained the position of constitutional customary law. ${ }^{65}$ The interwoven deterrent was, however, that much of the desperately needed modern legislation would unavoidably stand in contradiction with constitutional norms. The normal solution would be to change the constitution or, alternatively, empower the courts to undertake judicial review, thus ensuring that laws would not contradict the constitution. The problem was that both of these options were undesirable and could not be fitted in the constitutional path without serious deviation.

\footnotetext{
${ }^{60}$ As Jyränki, supra n. 32, p. 403 comments: 'The continuity in legal thinking from the period of autonomy to independence was remarkably strong, stronger than is usually thought'.

${ }^{61} \mathrm{O}$. Pekonen, 'The political transfer of parliamentary concepts and practices in the European periphery: the case of obstruction in late nineteenth- and early twentieth-century Finland', 37 Parliaments, Estates and Representation (2017) p. 281 at p. 282.

${ }^{62}$ Valtiopäiväjärjestys Ask 11/1869 [Ask is an abbreviation of Asetuskokoelma, i.e., the Official Collection of Enactments], the Diet Act.

${ }^{63}$ Jussila, supra n. 53, p. 346-347.

${ }^{64}$ Jyränki, supra n. 32, p. 408.

${ }^{65}$ Jyränki, supra n. 32, p. 403.
} 
Changing the text of old fundamental laws that Alexander I had promised to uphold in 1809 might risk compromising the legal basis of autonomy, leaving the door open for deeper Russification of the Grand Duchy. For the majority of the Finnish elite, who wanted to protect and preserve the constitutional foundation of autonomy, this was not something to be done lightly. For similar reasons, opening the door for judicial review was out of the question. This was because judicial power was within the reach of Russia. At that time, the domestic government and the highest judicial power were organised under the same roof, namely the Senate. This organ combined the functions of a cabinet and the highest court from 1816 until the early steps of an independent Finland. There were two separate divisions, the Economic Division (talousosasto) and the Judicial Division (oikeusosasto). Importantly, Russia chose individuals to fill positions in the Senate. In practice, this meant that judicial power ultimately lay in the hands of Russia. Now, to entrust judicial review into the hands of the Senate's Judicial Division would have meant surrendering the interpretation of fundamental laws to individuals who could have been favourable to the expansion of Russian power at the expense of the powers of the Grand Duchy.

As became clear from this complex situation, both of the seemingly obvious solutions to the constitutional dilemma regarding new legislation were, in practice, out of the question. In the Finnish view, the core essence of constitutional thinking was that the Tsar had pledged to govern Finland according to its existing laws and in particular constitutional laws. This essential idea was locked in to three key occurrences: 1772, 1789, and 1809. The path-dependent solution to the problem with new legislation had to be based, in a legal culture adhering generally to the idea of legalism, on earlier steps that limited freedom of choice if and when constitutional continuity was going to be preserved. ${ }^{66}$ That said, constitutional law would not necessarily have remained purely Gustavian. Old rules needed to be applied, and thus interpreted, in new situations. This meant, nevertheless, that certain fundamental features of the constitution were shaped and tuned under Russian pressure, yet at the same time they were based on old fundamental laws that were mixed

\footnotetext{
${ }^{66}$ It is quite possible that one of the unintentional consequences of the 1772 Form of Government was a slowly growing idea according to which governance should be solely laid down in a written constitutional document. Therefore, the idea of some kind of constitutional legal positivism was taking shape in the shadows of day-to-day politics and the tug-of-war between the nobility and the King: Jyränki, supra n. 32, p. 74.
} 
with the slowly growing political consciousness of an awakening nation. ${ }^{67}$ As a result, national identity and law became intertwined under the threat from the East. ${ }^{68}$

A constitutional solution was pioneered in connection with the draft 1878 Military Service Act (Asevelvollisuuslaki). It was realised that many of the provisions of the Bill were in clear contradiction to the 1789 Deed that secured the privileges of the Estates. The problem was clear and unavoidable because the Bill had to be passed. To put it simply, how to preserve the fundamental law without altering its text, yet at the same time pass required legislation known to be contrary to those very rules that needed to be kept unaltered? Moreover, to pass new law and leave constitutionality to the Senate's Judicial Division was, as explained above, inconceivable. ${ }^{69}$ In essence, a solution had to be devised within the Diet of the Estates in order to keep important constitutional interpretative power in the hands of the Finns. Critically, Russia had no direct reach inside the Diet, unlike the Senate. Crucially, the 1869 Diet Act provided that members of the Diet were not to follow any other rules in their capacity as a member; only 'the country's constitutional laws' were to be taken into account. ${ }^{70}$

A constitutionally feasible path had led to a situation in which the Finns simply had to come up with a solution that could put all the pieces in their correct places. This was a path-dependent tightrope-balancing act between legalism and political realism. What was done was technically simple; some articles of the legislative Bills were proclaimed to be constitutional as to their nature, and thus were passed under the same legislative procedure that would have been required for changing a constitutional document, namely support by three-quarters of the Estates. This solution enabled the passing of enactments contradictory to the constitution, though without changing the text of the constitutional documents themselves. In other words, an ingenious path-dependent solution was to eat the cake and yet at the same time to have the cake, namely to amend the constitution without changing its text.

\footnotetext{
${ }^{67}$ Husa, supra n. 24, p. 17-19.

${ }^{68}$ L. Björne draws interesting parallels between Finland and Norway in his book 'Threat from the East', Hotet från öster: drag i finsk och även norsk konstitutionell historia fram till 1809/1814 (Dreyers Forlag 2014).

${ }^{69}$ Husa, supra n. 24, p. 228-229.

${ }^{70}$ The Diet Act (1869), 7 §. 'An Estate Representative, in his work, is not under any other rules than constitutional laws of the country' ('Valtiopäivämies ei ole tätä tointa käyttäessä muiden määräysten kuin maan perustuslakien alainen').
} 
The solution that was devised also includes another important procedural peculiarity termed an exceptive law (poikkeuslaki). This is the result of a priori constitutionality control because these laws change the constitution substantively without altering the text of the constitutional document. Therefore, adoption of poikkeuslaki depends on a priori constitutional control and determining constitutionality takes place as part of the legislative process. In practice, the constitution is interpreted by the legislature in order to preventively remedy any detected unconstitutionality. The key outcome is clear. Exceptive laws are contrary to the idea of legal constitutionalism because they mean that the intended legislative act is conceived to be explicitly in conflict with the constitution and yet is passed by the legislature, even though under the same procedure that would be required to change the text of the constitution. What is more, exceptive laws are by-products of the fundamental solution to entrust the parliament (first the Diet) to take care of constitutionality control before parliamentary laws come into force. Now, discussing exceptive laws would require a paper on its own, so cannot be dealt with here in more detail. ${ }^{71}$ Nonetheless, suffice to note that the idea of changing constitutional laws without changing the texts of constitutional documents was already instilled in 1809 by the Tsar's pledge. ${ }^{72}$

The constitutional doctrine that was created is the institutional solution (one parliamentary committee reviews constitutionality preventively) that remains a functioning part of Finnish constitutional law and political constitutionalism. In the late Russian period, just before independence, the legislative assembly functioned as a constitutional bulwark against Russification. Constitutional interpretation ideology as to its nature was mostly unanimous and clear in terms of Finland's legal status: constitutional laws must be interpreted extremely narrowly and in autonomyfriendly mode. ${ }^{73}$ Much of the prestige that the Committee gained during these years was transferred to the budding constitutional practices of an independent country that chose not to rely on legal constitutionalism, instead relying on an interwoven constitutional doctrine rooted gradually in the constitutional system. The institutional core of this solution is to make one of the Committees of the Diet (later parliament) responsible for controlling the constitutionality of Bills. At first, it was the Diet's Legal Affairs Committee (lakivaliokunta) and then from 1906 onwards the Constitutional

\footnotetext{
${ }^{71}$ Jyränki, supra n. 32, p. 492-500; Husa, supra n. 24, p. 227-232. For a broader contemporary discussion see J. Lavapuro et al., 'Rights-based Constitutionalism in Finland and the Development of Pluralist Constitutional Review', 9 International Journal of Constitutional Law (2011) p. 505.

${ }^{72}$ R. Erich, Valtiosääntöjen säätäminen ja muuttaminen [Passing and Changing Constitutions] (WSOY 1909) p. 272-273 (which also mentions the 1878 Military Service Act as an example).

${ }^{73}$ E. Riepula, Eduskunnan perustuslakivaliokunta perustuslakien tulkitsijana [Constitutional Committee of the Parliament as Interpretator of Constitutional Laws] (Suomalainen Lakimiesyhdistys 1973) p. 73.
} 
Law Committee to which this central constitutional function was assigned. Thus it was Finnish constitutional invention that kept constitutionality control as an internal affair of the Grand Duchy rather than a power that would have been either directly in Russian hands or, at least, under Russian influence. $^{74}$

The newly crafted control model was first used in its fully developed form in 1882 when the Seat Farm obligation was abolished. ${ }^{75}$ The Bill was sent to the Law Committee, which was tasked with issuing a statement on constitutionality (and what legislative procedure was required) to another Committee that was dealing with the Bill substantively. In international comparison, this institutional solution was and is rare: in a situation when concerns exist about the constitutionality of a Bill, it was sent to a specialist Committee that had to evaluate and decide exclusively on the constitutionality issue. ${ }^{76}$ In practice, the Finnish Diet now (from 1882 onwards) had a specialist Committee tasked with providing an authoritative interpretation on the constitutionality of a Bill.

The new control mechanism rooted quickly as it was deemed an important means of safeguarding autonomy. In 1888, this practice was already described as 'a normal procedure'. In effect, the function of the Committee may be rightly described as quasi-judicial. ${ }^{77}$ Rather soon, the Committee started to use its earlier statements as a kind of precedent. The institutionally peculiar foundational idea was to admit that the Law Committee's interpretation was not necessarily the right one; however, it became de facto binding guidance for the Diet, so the Committee's statement on the correct legislative procedure had to be taken into account. That is to say, the Estates themselves assumed the role of guardians of the constitution. ${ }^{78}$ In other words, Finnish constitutionalism

\footnotetext{
${ }^{74}$ The idea itself was not completely novel because a similar type of idea had already been developed in the late eighteenth century: Jyränki, supra n. 32, p. 68.

${ }^{75}$ The statement by the Law Committee is part of the Finance Committee's Report (3/1882) on Bill 33/1882. Formally the issue concerned $\S 18$ of the 1772 Constitution, although in practice the problem arose because so-called seat farms enjoyed certain freedoms from taxes and tithes. The paragraphs of this law do not indicate that it is an exceptive law; instead, the legislative order can be seen in the introductory words - a custom that is still followed today.

${ }^{76}$ From the point of view of comparison, there are certain similarities with the UK House of Lords Constitution Committee. However, the institutional, historical, contextual, and practical differences are perhaps too great for a meaningful juxtaposition. For more about the UK institution, see Select Committee on the Constitution, 15th Report of Session 2010-12 The Process of Constitutional Change (HL 177 2011) p. 34-36.

${ }^{77}$ Jyränki, supra n. 32, p. 442-444.

${ }^{78}$ Jyränki, supra n. 32, p. 446-447.
} 
developed from the outset as political constitutionalism and developed as such during most of the twentieth century. ${ }^{79}$

In the late nineteenth century and at the beginning of the twentieth century (1899-1905) Russia started to severely limit the special status of the Grand Duchy. This period was followed by a second period of Russification (1908-1917) that maintained similar goals regarding Finland. In Finnish, these periods are called collectively the Times of Oppression (sortokaudet). Eventually, Finnish opposition to Russification played an important role leading to the declaration of independence in 1917. Notably, Finnish opposition to oppression was constitutional in nature. Arguments were based on existing constitutional documents and customs. In practice, Finns resisted Russification by making legal - and ultimately legalistic - arguments when they sought to defend the status of the Grand Duchy. ${ }^{80}$ During the second period of Russification, the crux of the Committee's work, both qualitatively and quantitatively, focused on interpreting the constitutional position of Finland defensively. ${ }^{81}$ As a corollary, the Constitutional Law Committee became a core institution, as indeed it remains to this day.

Russification started with a constitutional shock move by the Tsar in 1899 with the February Manifesto, which limited autonomy and the former constitutional legacy. In short, the Manifesto was aimed at abolishing Finland's fundamental laws. ${ }^{82}$ Nicholas II's explicit purpose was to make earlier constitutional laws obsolete. The Tsar added with his own hand a marking in the margins of the presentation agenda of the Manifesto that ' $[\mathrm{I}] \mathrm{t}$ is time to forget the [1772] Form of Government'. ${ }^{83}$ According to the Manifesto's Preamble, legislative issues concerning the general interests of the Empire 'cannot be exclusively treated by the institutions of the Grand Duchy' ${ }^{84}$ In the end, Russification tempered the institutional position of the Diet as a constitutional key player. Mounting Russian pressure impelled lawyers, historians, politicians, and ordinary people to defend Finnish autonomy and the constitutional basis on which it relied. ${ }^{85}$ These developments had a lasting impact on Finnish legal culture, which learned to place its belief in legislative procedures

\footnotetext{
${ }^{79}$ See also M. Hidén, 'Constitutional Rights in the Legislative Process', 17 Scandinavian Studies in Law (1973) p. 95.

${ }^{80}$ S.D. Huxley, Constitutional Insurgence in Finland (Studia Historica 1990). See also Pekonen, supra n. 61, p. 295.

${ }^{81}$ Riepula, supra n. 73, p. 117 (with exact numerical data).

${ }^{82}$ Keisarillisen Majesteetin Armollinen Julistuskirja Ask 3/1899 [The Gracious Manifesto of the Imperial Majesty].

${ }^{83}$ Jyränki, supra n. 32, p. 451; Jussila, supra n. 53, p. 619.

${ }^{84}$ See also Jussila, supra n. 53, p. 615-634.

${ }^{85}$ P. Kastari, Suomen valtiosääntö [Constitution of Finland] (Suomalainen lakimiesyhdistys 1977) p. 46-47.
} 
stipulated in a detailed manner but also adding and allowing customary elements as an integral part of a living constitutional system. ${ }^{86}$

$<\mathrm{H} 1>$ Centrality of the Constitutional Law Committee in constitutionality control

The most influential Finnish constitutional lawyer and professor during the twentieth century, Paavo Kastari (1907-91) described the Finnish solution as 'a tactical trick with more far-reaching consequences than any contemporaries could have guessed. Later, developed as a systematic modus operandi, it became a typical feature of our constitution and a symptomatic aspect of our constitutional perception'. ${ }^{87}$ Even though Kastari called the Finnish solution a tactical trick, it was not assumed hastily. In fact, it had been doctrinally considered and was backed by theoretical thinking. This was demonstrated by Leo Mechelin (1839-1914), an important law professor and statesman. Mechelin, who was keen to defend the constitutional position of the Grand Duchy, developed an idea according to which one special Committee of the Diet ought to specialise in interpreting constitutionality in connection with Bills. ${ }^{88}$ And that, as we have seen, is precisely what happened in practice.

Under this approach, the idea was that one of the Committees should take responsibility for giving 'the right' constitutional interpretation to the whole Diet. ${ }^{89}$ Remarkably, this manner of organising constitutionality control today remains a distinctive feature of the Finnish constitution even though the system was slightly revised in the 2000 total constitutional reform. ${ }^{90}$ From the point of view of path dependence, it is important that the solution devised in the Diet of the Estates during the period

\footnotetext{
${ }^{86}$ A. Jyränki and J. Husa, Valtiosääntöoikeus (Lakimiesliiton kustannus 2012) p. 29.

${ }^{87}$ Kastari, supra n. 85, p. 45.

${ }^{88}$ In Précis du droit public du Grand-Duché de Finlande (1886) Mechelin strongly defended Finland's constitutional position. This short publication, a learned pamphlet, was later also published in German (enlarged version) and English. Mechelin's text had an impact especially outside Russia and it spread effectively the idea according to which Finland was a state, distinct from Russia: Jussila, supra n. 53, p. 542. Mechelin was certainly not the only Finnish legal scholar presenting these arguments, though. See also, e.g. R. Hermanson, Finlands statsrättsliga ställning [Finland's Constitutional Position] (Edlund 1892). ${ }^{89}$ Jyränki, supra n. 32, p. 439-442.

${ }^{90}$ For a general description, see A. Jyränki, 'Die neue Verfassung Finnlands', 56 Zeitschrift für öffentliches Recht (2001) p. 113. According to the 2000 Constitution ( $\$ 106$ ), the courts must give preference to the Constitution when they decide a case if the application of a parliamentary law would be in manifest conflict (in Finnish 'ilmeinen ristiriita') with the Constitution. This article was adopted as 'an alternative' to establishing a Constitutional Court: Government Proposal (Hallituksen esitys 1/1998) p. 53-54. In a small number of cases, starting from 2004, the courts have applied Article 106 but in the overall picture judicial review by the courts plays a minor role in terms of guarding the constitutionality of parliamentary laws: Husa, supra n. 23, p. 186-187. Weak judicial review was a modified legal transplant from Sweden (such as it was in 1979-2010): J. Nergelius, 'Judicial Review in Swedish Law: a Critical Analysis', 27 Nordic Journal of Human Rights (2009) p. 142 (which explains the Swedish situation just before the 2010 reform).
} 
of the Grand Duchy transposed successfully to an independent Finland. Likewise, the authoritative status that the Law Committee had acquired during the late nineteenth and early twentieth centuries was transferred to the new Constitutional Law Committee. ${ }^{91}$ In other words, there were no side steps from the path of constitutionality control.

The civil discontent and unrest that broke out in Russia following military defeat by Japan provided an opening for parliamentary reform in Finland in Autumn 1905. The hopelessly outdated Diet of the Four Estates supported a Bill calling for the establishment of a unicameral Parliament and the introduction of universal suffrage. Weakened because of military defeat by Japan - leading to a short period of quasi-constitutional monarchy - the Tsar approved the proposal and thus the Finnish parliament (Eduskunta) was established in $1906 .{ }^{92}$ Finland's position as a Grand Duchy with special status was also confirmed in the first Russian Constitution in $1906 .{ }^{93}$ From a historical viewpoint, the Parliament Act of 1906 was a monumental constitutional reform: ${ }^{94}$ in short, 'a profound break from the past' ${ }^{95}$ The old Diet of the Estates was replaced by a modern unicameral Parliament; moreover, universal and equal suffrage was introduced. In defiance of otherwise large-scale and deep-reaching reform, including abolition of the Diet and creation of a modern parliament, the constitutional control model did not change even though a new special Committee was established. The Constitutional Law Committee saw the light of day. Under the Parliament Act of 1906, this special Committee had to 'prepare legislative issues that concern passing, changing, explaining or abolishing the constitution'. ${ }^{96}$ The existing practice was merely described and codified in the new constitutional document, first in 1906 and later - with slight modifications in wording - in 1928. Constitutionality control followed the path of continuity, unlike the 1906 reform in other ways, whereas 1928 was more or less a technical reform updating parliamentary procedures. ${ }^{97}$

\footnotetext{
${ }^{91}$ Jyränki and Husa, supra n. 86, p. 32.

${ }^{92}$ R.B. Mckean, 'The Constitutional Monarchy in Russia, 1906-17', in I.D. Thatcher (ed.), Regime and Society in Twentieth-Century Russia (Palgrave Macmillan 1999) p. 44-67.

${ }^{93}$ According to the Russian Constitution of 1906 'The Grand Duchy of Finland, while comprising an inseparable part of the Russian state, shall be governed in its internal affairs by special decrees founded upon special legislation'. For a more detailed discussion on this constitutional reform, see e.g., G. Doctorow, 'The Fundamental State Laws of 23 April 1906', 35 Russian Review (1976) p. 33.

${ }^{94}$ Suomen Suuriruhtinaanmaan Valtiopäiväjärjestys Ask 26/1906 [The Parliament Act of the Grand Duchy of Finland].

95 J. Teljo, Suomen valtioelämän murros [Turning Point of Finnish State Life] (WSOY 1949) p. 228.

${ }^{96}$ In Finnish $40.1 \S$ 'Perustuslakivaliokunnan tulee valmistella sinne lähetetyt asiat, jotka koskevat perustuslain säätämistä, muuttamista, selittämistä tai kumoamista'.

${ }^{97}$ Kastari, supra n. 85, p. 44-48.
} 
From the point of view of continuity, the new Committee continued the tradition from the previous century. After independence, much of the earlier constitutional practice was transferred to an independent Finland. This concerns not only the institutional solution and the legislative process but also the interpretative modus operandi, relying on academic experts and earlier statements of the Committee itself, which was born in the late nineteenth century. Many interpretations concerned, in an almost routine-like manner, property rights, and the interpretative tradition continued..$^{98}$ This is reflected in the fact that change is minimal in the constitutional text concerning constitutionality control between the Parliament Acts of 1906 and 1928. ${ }^{99}$ More importantly, not only the text and interpretative tradition but also the accompanying constitutional thinking continued their existence as a part of the constitutional framework of an independent country. In a broad legal-cultural sense, legalism prevailed. ${ }^{100}$ At an early stage, even in the mid-1920s, the Committee assumed a key role in constitutional interpretation. As an illustration of its power we can register how the 1919 Constitution did not specify - and the same applies to the Constitution in force today - the procedure by which exceptive laws could later be changed: as ordinary laws or as constitutional laws. The Constitutional Law Committee created a doctrine in the mid-1920s that remains valid today, even though rarely used. ${ }^{101}$ As a result, the constitutionality control system is the bestpreserved part of the constitutional culture built on a path laid down in 1772.

The key question, from the viewpoint of path dependence, is why the system of constitutionality control was not reformed when the new Constitution - literally Form of Government - was drafted and passed in 1919. ${ }^{102}$ The Finns had already tried to create a new Form of Government in 1907 under the leadership and initiative of Mechelin, but the Bill was stopped by Russia's prime

\footnotetext{
${ }^{98}$ Jyränki, supra n. 32, p. 503.

${ }^{99}$ Valtiopäiväjärjestys (7/1928) § 46 declared that it was the Constitutional Law Committee's obligation to 'prepare the matters sent to it relating to the enactment, amendment, expounding or repeal of a Constitutional Act or to legislation that is in close substantive connection with a Constitutional Act'.

${ }^{100}$ P. Letto-Vanamo and D. Tamm say that '... the relation to Russia has had an impact on Finnish society as well as on societal and legal thinking, which may differ from that of the other Nordic countries. Especially, attitudes towards law have been more legalistic than in the other Nordic countries': 'Nordic Legal Mind', in Letto-Vanamo et al., supra n. 5, p. 1 at p. 6-7.

${ }^{101} \mathrm{PeVL} 15 / 1924$ [PeVL is an acronym of perustuslakivaliokunnan lausunto, i.e. a Statement by the Constitutional Law Committee]. According to this doctrine, if later changes do not go further than the original exception, then they can be passed in the normal legislative order.

${ }^{102}$ Hallitusmuoto (AsK 94/1919) was the first and most important Finnish constitutional document from 1919 to 2000. In literature, hallitusmuoto is typically translated as the Constitution but a literal - and more fitting - translation is 'form of government'. In this, it followed the Swedish tradition. In Swedish, the title was more exact, as it was Regeringsform för Finland, i.e. 'Form of Government for Finland'.
} 
minister. ${ }^{103}$ The answer to why the control mechanism remained unchanged lies in the significance of the constitutional path.

After independence, reform of the constitutionality control mechanism would have been an option. However, the 1919 Form of Government did not change a system devised in the previous century and under very different circumstances. Nevertheless, Gustavian constitutional rules acted as a loose paradigm for the 1919 Constitution. ${ }^{104}$ This is the point where we can see the significance of path dependence. Whereas the Constitutional Law Committee had gained trust and dignity, as a key guardian of autonomy, the Supreme Court - the former Judicial Division of the Senate - was conceived as less trustworthy and less dignified as the highest institution of constitutionality control. In short, institutional and legal cultural continuity played an important role; it limited the actual space for new constitutional patterns to emerge by limiting the possibility to transfer constitutionality control to the Supreme Court. Accordingly, the Parliament inherited the role of guardian of the constitution. ${ }^{105}$

In 1917, discussions took place on the possibility of allowing constitutional judicial review. Nevertheless, little willingness was shown to giving constitutionality control to a purely judicial organ. Thus, propositions by politicians to establish judiciary-based constitutionality control did not succeed. Nevertheless, after the Civil War of 1918, some further discussion took place about giving full constitutional power to judicial organs. ${ }^{106}$ During the drafting of the Form of Government, formulations were circulating on this matter but in the end the finally accepted version did not change constitutionality control. All the different versions that would have allowed constitutional judicial review were wiped away by a Parliament that guarded its power to take care of constitutionality control preventively, that is, before a Bill becomes an official parliamentary Act. ${ }^{107}$ Unsurprisingly, then, in 1919 the Parliament rejected the Supreme Court's competence for judicial review by a vote of 104 to $77 .{ }^{108}$ The constitutional space left for the judicial branch in constitutionality control was non-existent. ${ }^{109}$

\footnotetext{
103 Jussila, supra n. 53, p. 704-710.

${ }^{104}$ Jussila, supra n. 53, p. 754.

105 Riepula, supra n. 73, p. 49-52.

${ }^{106}$ For a broad analysis of the civil war, T. Tepora and A. Roselius (eds.), The Finnish Civil War 1918: History, Memory, Legacy (Brill 2014).

${ }^{107}$ Riepula, supra n. 73, p. 336-338; Jyränki, supra n. 32, p. 515-519.

108 Jyränki, supra n. 32, p. 515-516.

${ }^{109}$ The Form of Government (1919) enabled ( $\left.\$ 92.2\right)$ the courts to review the constitutionality of Decrees but not Parliamentary Acts. There was no direct prohibition for the courts (and other public authorities) to control the constitutionality of laws passed by parliament but, in practice, the prohibition was made on an $e$
} 
Yet independence brought something new to the system, especially after 1919. A novel constitutional custom came into being: the Constitutional Law Committee began regularly to seek statements from outside experts. Before 1919, there had been no need for outside expertise simply because many of the Committee members were public law experts. Later, it gradually became a constitutional custom for the Committee regularly to hear public law professors. During the following decades, this was to become a signature feature of constitutionality control. ${ }^{110}$ The practice of hearing outside experts, and giving great weight to written their statements (lausunto), is still a customary part of the Finnish constitution. ${ }^{111}$ Even though, no doubt, the primary source of constitution is a written constitutional document, the de facto significance of outside experts cannot be overstated. ${ }^{112}$ This path-dependent tailored constitutional custom is not - and here is the thing part of a codified constitutional document. ${ }^{113}$ Historically we can note, nevertheless, that when it comes to the written constitution, very little is left of the text of the 1772 constitution. ${ }^{114}$ Political constitutionalism, on the other hand, has proved to be quite a resilient feature. Only relatively recently has constitutional development concerning judicial review crawled towards more active courts. This development has been due to European Union law, international human rights, and the growing domestic importance of constitutional rights. ${ }^{115}$

\section{$<\mathrm{H} 1>$ Conclusions}

What should we think of the constitutional lock-in moments of the Finnish constitutional system?

contrario basis, i.e., because the norm was silent about it, it was not deemed legally possible. In other words, the prevailing interpretation was that the courts had no role in constitutionality control of laws passed by the legislature. Kastari, supra n. 85, p. 256-258.

${ }_{110}$ Jyränki, supra n. 32, p. 511-515.

${ }^{111}$ Jyränki and Husa, supra n. 86, p. 353 say that 'As it is the expert-institution has developed so regular, frequent and broad that it can be seen - though not formally - as an elemental part of the institution'.

${ }^{112}$ Husa, supra n. 24, p. 224-227.

${ }^{113}$ For a wider discussion on how constitutionality control actually works, see V. Saario, 'Control of the Constitutionality of Laws in Finland', 12 American Journal of Comparative Law (1963) p. 194 and P. Länsineva, 'The Constitutional Committee of Parliament: The Finnish model of norm control', in M. Sakslin (ed.), The Finnish Constitution in Transition (Finnish Society of Constitutional Law, 1991) p. 68.

${ }^{114}$ However, in 1772 the general qualifications for public office said $(\S 10)$ such that the chosen person should be 'the most skilled, worthiest, and best qualified for the vacant place' ('förståndigaste, värdigaste och til then lediga beställningen tienligaste Personer', the 2000 Constitution ( $\$ 125.2)$ says that the 'general qualifications for public office shall be skill, ability and proven civic merit' ('Yleiset nimitysperusteet julkisiin virkoihin ovat taito, kyky ja koeteltu kansalaiskunto').

${ }^{115}$ T. Ojanen, 'From Constitutional Periphery toward the Center', 27 Nordic Journal of Human Rights (2009) p. 194. For a broader historical analysis, from the post-war years to the mid-1990s, see J. Salojärvi, Human Rights Redefining Legal Thought: The History of Human Rights Discourse in Finnish Legal Scholarship (Springer 2020). 
Constitutional lock-in moments are distantly related to so-called constitutional moments. Ackerman observed the constitutional system of the United States, arguing that it has undergone a number of crucial transformations since it came into force in 1789. ${ }^{116}$ Yet Ackerman's theory goes beyond the United States as it seeks to present a description that explains in a more general manner reasons behind key constitutional transformations and how they come about. ${ }^{117}$ The key difference between these two related notions is that lock-in moments are historical and they do not require citizens to act in their capacity as a sovereign people or otherwise express their momentary political enthusiasm. ${ }^{118}$ Of course, a lock-in moment and a constitutional moment may overlap time-wise but they are, nonetheless, different points of view: one underlines the idea of path in which certain choices limit future choices, whereas the other underlines the political deliberation of the people exercising their higher law-making power at certain constitutionally pivotal moments. ${ }^{119}$ Moreover, Ackerman's theory is very American in its nature, and the assumptions it makes concerning the nature of the constitution and democracy are not directly applicable to the Finnish constitutional system or its history, which are very different from the American experience.

Importantly, for a constitutional lock-in moment to be successful, some aspects may also depend on fortune. Providentially, Finland - in constitutional terms - was a backward area in 1809. That enabled the Russian Tsar to continue on the existing constitutional basis, also serving for pacification of this newly acquired region. When changing times required new legislation in the late nineteenth century, a novel solution was crafted to ensure constitutional continuity and legitimacy. By 1906, the role of the Law Committee had become that of an integral constitutional actor, which meant that the new Constitutional Law Committee continued on a path already laid. Independence and the constitutional documents of 1919 and 1928 did not change a constitutionality control system that was already locked in. The reform of 2000 enabled the courts to undertake judicial

\footnotetext{
${ }^{116}$ B. Ackerman, We the People: Foundations (Belknap Press 1991). For a more concise discussion on Ackerman's book, see M. Klarman, 'Constitutional Fact/Constitutional Fiction: A Critique of Bruce Ackerman's Theory of Constitutional Moments', 44 Stanford Law Review (1992) p. 759.

${ }^{117}$ See B. Ackerman, The Future of Liberal Revolution (Yale University Press 1992) (applying the idea of constitutional moments against the backdrop of transformations that took place in the early 1990s in Central and Eastern Europe).

${ }^{118}$ Ackerman, supra n. 116, p. 6-7 spoke of higher law-making that would take place during an intense period of political deliberation so that the (American) people would have a direct role leading to enduring constitutional change. During moments like these, the public would speak as 'We the People'.

${ }^{119}$ We can also see that Ackerman's theory is based on an idea of temporal compression and not the extended period that the path dependency idea is based on. See also M Tushnet, The New Constitutional Order (Princeton University Press 2003) p. 3-4.
} 
review, but in a limited manner. The ad hoc Committee for checking the Constitution Act did not propose changes concerning judicial review in $2010 .{ }^{120}$

The crucial path dependent-related question, however, is this: how long can Finnish constitutionality control exceptionalism survive in a world of ever-growing judicial expansion and accompanying legal constitutionalism? There is no doubt that the European and global constitutional environment affects the Nordic constitutions, Finland included. ${ }^{121}$ To an extent, the global constitutional environment affects Nordic constitutional thinking in general because it challenges the combination of timid judicial review, political constitutionalism, and the principal primacy of national Parliaments. ${ }^{122}$ However, because Finland has a specific form of constitutionality control, it faces pressures that are of a fundamental nature - because of the lock-in in the way the system takes care of controlling the constitutionality of laws. At the end of the day, the challenge concerns constitutional culture and constitutionalism. Even though it is quite likely that judicial review will grow at the expense of the parliament, it is clear that rights-oriented legal constitutionalism and legislature-oriented Finnish constitutionalism are not easy to combine. The problem is not so much that the Constitutional Law Committee would be ill suited for rightsoriented interpretation but rather that the Committee is becoming a gradually more politicised arena. In addition, the role of outside experts that is based on constitutional custom is conceived as more problematic, with experts accused of offering politically flavoured views on constitutional law. Moreover, there have been some signs of growing mistrust of the Committee among politicians. ${ }^{123}$

Finally, layering is also an important mechanism in path dependence. What happens in the process of layering is that an institution changes incrementally because additional rules and institutional structures are added on top of the existing institution. Consequently, each new added layer may bring about a small alteration to the institution. This does not mean that the institution will not change, because small cumulative changes may lead to the eventual transformation of the original institution. ${ }^{124}$ Based on its historical path, change by incremental accumulation is probably the case

\footnotetext{
${ }^{120}$ Perustuslain tarkistamiskomitean mietintö (KM 9/2010) [Report of the Constitution Act Checking Committee] p. 126-128.

${ }^{121}$ M. Suksi, 'Markers of Nordic Constitutional Identity', 37 Retfard (2014) p. 66 at p. 77.

122 J. Husa, Nordic Reflections on Constitutional Law (Peter Lang 2002) p. 185.

${ }^{123}$ During 2015-2019 the Government struggled (and failed) to achieve a huge social, health care, and regional government reform. Numerous Bills were rejected over and over again by the Constitutional Law Committee, drawing the experts into the political arena. About the failed reform, see Final Report of the Regional Government, Health and Social Services Reform (Ministry of Finance Publications 2019).

${ }^{124}$ Boas, supra n. 18, p. 49.
} 
with the Finnish system of constitutionality control, too. It seems likely that Finland will remain a system that assigns a key role to non-judicial actors in upholding the constitution. 